\title{
Improving Students' Reading Comprehension of Descriptive Texts through Cognitive Strategy at Grade VII-2 of SMPN I Indra Praja Tembilahan
}

\author{
Adam \\ English Education Department \\ University of Riau Kepulauan \\ adam@fkip.unrika.ac.id
}

\begin{abstract}
This research aimed to (1) know whether or not cognitive strategy can increase students' skill in writing descriptive texts, and (2) know what factors can influence the increasing of those writing skills. This research categorized as action research which conducted in two cycles. Each cyles consisted of four times meeting. Each of them composed of plan, action, observation, dan reflection. The participant in this research was all 22 students of VII-2 SMPN I Indra Praja Tembilahan. The data was collected from (1) Observation sheet; students, teacher, lesson procedures/plan, (2) Field note, (3) Interview, and (4) Writing test. It was found in this research that the use of cognitive strategy can increase students' skill in writing descriptive texts. The finding of this research shown that there was an increasing of students' mean score above minimum criteria of minimum learning mastery standard (75).The factors that influenced students' skill in writing descriptive text were (1) reading material given to students, (2) students' motivation, and (3) teachers' approach to students. It can be concluded that the application of cognitive strategy in teaching reading descriptive texts gave positive results shown by the increasing of students' skill in reading descriptive texts.
\end{abstract}

Keywords: students' reading comprehension of descriptive text, cognitive strategy

\section{INTRODUCTION}

Reading is one of the English language skills that have to be mastered by all of students. Having good reading English skill is very important for the students. It can help the students to enlarge their knowledge because they can get a lot of information through reading. Reading skill is also very important in learning English as a foreign language. The aim of teaching reading is to make students able to read English text effectively and efficiently. They do not only have to understand the structure of the text explicitly but more important they must comprehend the meaning implicitly. 
Reading does not only improve their reading ability but also by having reading activity they can increase their knowledge. Burnes (2007) states that reading is a meaninggetting activity in which reader and writer interact. The interaction will be facilitated by strategy designed to reduce the gap between written and oral language models. Moreover, Burnes explain that reading is comprehended written discourse. It means that reading is an interactive process, a process in which the reader engages in an exchange idea with the writer via text. The exchange usually has a purpose and takes place within a specific context or a setting.

Junior high school students are taught reading of various kinds of text. Every semester, students learn reading different text types. School-Based Curriculum (KTSP) for junior high school gives obligation to the students to develop their reading skill and also to comprehend types of texts based on their grades. The purpose of teaching reading at the Junior high school is making the students able to respond the meaning and structural text in the functional text and short essay. However, there are 5 texts which are taught in junior high school; Narrative text, Procedural text, Recount text, Descriptive text, and Report text. Each genre of text is unique based on its characteristics, language feature, and schematic structure.

According to the curriculum, the aim of teaching reading at seventh grade of junior high school is making the students able to respond the meaning and structural text in the functional text and simple short essay in the form of descriptive and procedural text to interact with surrounding. The aim of the teaching reading itself is not always achieved well since there are some problems are appeared in teaching learning process in SMPN 1 Indra Praja Tembilahan. Most of the students have difficulty in constructing meaning as they read from descriptive texts. According to Gerot and Wignell (2008), descriptive text is text type that describes a particular person, place or things. Similarly, Cavanagh (2008) also states that descriptive can occur as 'stand alone' texts. They are often part of a longer text, such as the description of a character or setting in a story or biography.

The result of the writer pre observation shows that the students at grade VII-2 had some problem in reading descriptive text. These problems probably occurred because the teacher used conventional strategy. It means the teacher only asked the students to read the text and answer the question directly. Consequently, students were not able to get good result in reading. This situation was probably the cause of the students' problem in reading. She then concluded some problems cause students difficulty in reading comprehension. The first problem that influenced the students' ability in comprehending reading texts is because they feel reading was boring and uninteresting activity. The second problem is the teaching and 
learning process. Third is they cannot recall the information from the text. Fourth problem is teacher's strategy in teaching reading.

Coping with those problems, the teacher should find a more appropriate reading strategy to increase the students' ability in comprehending descriptive text. The teacher should provide a more helpful technique to help the students to comprehend descriptive texts better and easier. The strategy that the researcher used in this research was cognitive strategy.

According to Oxford (2010), Cognitive Strategy such as summarizing or reasoning deductively, enables learners to understand and produce new language by many different means. Cognitive Strategy is essential in learning a new language. It is unified by common function; manipulation or transformation of the target language of the learners. This is to say that Cognitive strategy is an instructional approach which emphasized the development of thinking skills and processes as a means to enhance learning. The aims of Cognitive strategies are to enable the students to become more strategic, self reliant, flexible, and productive in their endeavors.

While Oxford (2010) offered four steps in cognitive strategy, they are:

\section{a) Practicing.}

\section{Repeating}

The strategy of repeating might mean reading a passage more than once to understand it more completely. A profitable technique is to read a passage several times, each time for different purposes.

\section{b) Receiving and sending messages}

\section{Getting the idea quickly}

This part helps the students in on exactly what they need or want to understand, and it allows them to disregard the rest or use it as background information only. Two techniques constituting this strategy are skimming and scanning.

\section{Using resources for receiving and sending message.}

This strategy involves using resources to find out the meaning of what is read in the new language, or to produce messages in the new language.

c) Analyzing and reasoning. The strategy in this set help learners to use logical thinking.

\section{Translating}

Translating allows learners to use their own language as the basic for understanding what they read in the new language. 


\section{d) Creating structure for input and output.}

\section{Taking notes}

The students will write down the main idea or specific points.

\section{Highlighting}

This strategy emphasize the major points in a dramatic way, through color, underlining, capital letters, initial capitals, big writing, bold writing, boxes, circles and so on.

In general, studies in both L1 and L2 reading research provide a binary division of cognitive strategies as bottom up and top down. In this approach, reading is meant to be a process of decoding; identifying letter, words, phrases, and then sentences in order to get the meaning. In addition, Sahan (2012:4) states that cognitive strategy refer to the steps or operations used in learning or problem solving which require direct analysis, transformation, or synthesis of learning materials. They operate directly on new information and control it to promote learning. They help the students to understand and produce the new language by repeating, summarizing, reasoning deductively, predicting, analyzing using context clues, note taking, and practicing with the specific aspects of the target language such as sentence structure and unknown vocabulary.

Based on discussions above, an action research should be done to solve the students' problem. The research is carried out to find whether cognitive strategy could improve the students' reading comprehension of descriptive texts and what factors influence the improvement of the students' reading comprehension of descriptive texts through cognitive strategy.

\section{METHODOLOGY}

The type of this research is Classroom Action Research. Classroom Action Research conducted in a classroom to improve teaching and learning process. Kemmis and Mc. Taggart (2008) state that classroom action research is a cyclic process where there are some steps to do that the researcher should know. There are four fundamental steps of the action research, they are plan, action, observation, and reflection. Hopkins (2008), classroom Action Research is an act undertaken by teachers, to enhance their own or a colleague's teaching, to test the assumption of educational theory in practice, or as a means of evaluating and implementing whole school priorities. The participants of this research were the researcher, the collaborator and 22 students in class VII-2 of SMPN 1 Indra Praja Tembilahan in 2017/2018 academic year. The data in the research were gathered from: (1) observation 
sheets for students and teacher, (2) field notes, (3) interviews, and (4) reading comprehension tests.

\section{RESULTS}

Findings of the research contain analysis of two different kinds of data; quantitative and qualitative data gathered in the research is aimed to answer whether cognitive strategy could improve the teaching and learning process in teaching reading of descriptive texts at grade VII-2 of SMPN 1 Indra Praja Tembilahan. While the qualitative data answered the second question about what factors influence the improvement of the students' ability in comprehending descriptive texts at grade VII-2 of SMPN 1 Indra Praja Tembilahan.

\section{The Improvement of the Students' Ability in Comprehending Descriptive Texts.}

After doing the research, the writer found that cognitive strategy could improve the students' ability in comprehending descriptive text. During two cycles in 8 meetings, the result shows that the students could comprehend descriptive texts better than before the research. It was indicated from the improvement of average score of the students' ability in reading descriptive texts at the end of cycle two. Moreover, there were also improvements of students' reading comprehension for aspect of comprehending descriptive texts. Finally, the following are the detail explanation about the teaching and learning process and findings of the research.

\section{Cycle One}

At the beginning of the treatment in cycle one, the teacher explained everything about the teaching and learning process in comprehending descriptive text to the students. She explained the process in comprehending descriptive texts through cognitive strategy. She did the cycle one in four meetings; three meetings for treatments and one meeting for post test. In the cycle one, the researcher explained in detail by giving some examples about descriptive texts. Then, she introduced and explained about cognitive strategy to the students because she they not know how to use this strategy. She explained the procedures and gave some examples about how to use cognitive strategy. After that, she checked the students' understanding about procedures by asking question. Then, the researcher implemented this technique collaboratively during teaching and learning activities in the classroom 


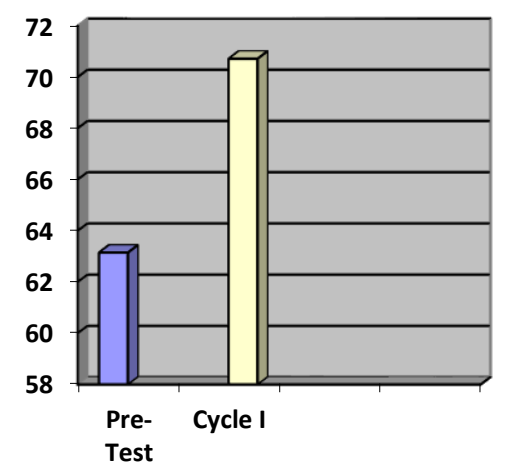

Graph 1. The comparison between students' average score of reading comprehension Pretest and Cycle I

Based on the students' reading comprehension of descriptive text result in cycle I, the researcher pointed out that the students' average score in reading comprehension of descriptive text test cycle I was 70.72 , increases 7.57 point comparing with the students' average score in pre-test (63.15). It could be concluded that the students' average score in reading comprehension test in cycle I has increased comparing with the students' average score in pre-test. There were eight students who could achieve the minimum criteria (KKM) or reach complete score of English subject in reading comprehension descriptive texts test cycle I. Whereas, in the pre-test there were only four students who could achieve the minimum criteria achievement $(\mathrm{KKM})$ or reach complete score.

\section{Cycle Two}

In the second cycle, the teacher only reviewed her explanation about cognitive strategy in comprehending descriptive texts. She directly gave another example about the technique. As usual, she gave a topic to be discussed for each meeting in cycle two.

She explained cognitive strategy to the students more slowly and comprehensively. Then after giving explanation about cognitive strategy, the researcher introduced about descriptive text to the students. She wrote the title of the text on the whiteboard. The researcher tried to motivate the students by encourage the students to thinks based on the title she gave. Then, the researcher gave modeling to the students how to do the strategy. Then after they understood the researcher's explanation, she asked the students to practice by themselves. First she asked them to read the text several time until they understand the text. After several minutes, the teacher checked the students work. She asked how many time the students need to comprehend the text. Then, the researcher asked the students to get the idea 
of the text. In getting the ideas, the students did scanning and skimming. The researcher gave modeling again to the students how to do this part first. She showed to the students how to scanning and skimming a text. In this strategy the researcher interacted with the students as dialogue and she also helped them during the dialogue. If the students confused about the text, they did not know the meaning of some words. The researcher monitored the students' activity by walking around them while ask them whether they have any problem or not in this strategy. At the end of the class, the researcher gave task to the students in order to know their comprehension after learning through cognitive strategy.

This is the end of all treatments in the research. In order to make it clear, the students' average score in cycle II comparing with the students' average score in cycle I can be seen in the following graph:

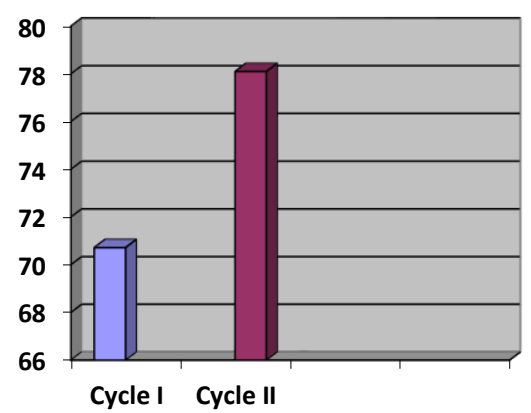

Graph 2. The comparison between students' average score of reading comprehension test in Cycle I and Cycle I

After all, the use of cognitive strategy successfully improved the students' ability in comprehending descriptive texts. Based on the data from cycle I and cycle II, the students' ability in comprehending descriptive text could be better improved through cognitive strategy. In detail, the improvement can be seen in the following graph: 


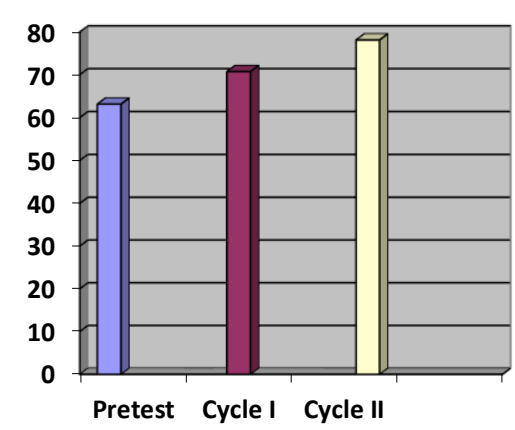

Graph 3. The improvement of the students' reading comprehension of descriptive texts

From the graph above, the students' average reading score from the beginning until the end of the research are clearly shown. The result of the students' score began on 63.15. it indicated that the result was still low. Therefore, teacher needed to apply an appropriate strategy to improve the students' reading comprehension of descriptive texts. Then, treatments in first cycle could improve the students' reading comprehension of descriptive texts up to 70.72 . It means that the students' ability in comprehending descriptive texts was improved through cognitive strategy.

\section{Factors that Influence the Improvement of Students' Ability in Comprehending Descriptive texts}

Based on the implementation of cognitive strategy in teaching descriptive text and the findings of this research, the researcher found that the effective uses of cognitive strategy that could improve the students' reading comprehension of descriptive text as follows:

\section{The materials used was interesting}

Based on the result of observations, field notes, and interview while teaching and learning process of reading comprehension of descriptive text through cognitive strategy in classroom, it was found that teaching material was one of the factors influenced the change of students' reading comprehension ability through cognitive strategy. Below is the sample of scripts from the collaborator's questions and students answer during interview section:

Collaborator : "Do you like the texts given by the teacher?"

Student 1 : "Yes, I do. I like the material. The material given is interesting".

Student 3 : "Of course Mrs. I like the text entitled My mother because it remembering me of my mother".

Student 6 : "Yes, Mrs. It is interesting, and I can get the idea".

Student 8 : "I like it Mrs. I get new information from Veterinarian text".

Student 10 : "Those texts are interesting, I don't get bored while reading".

Students' Motivation 
Student motivation was one of the factors that influenced the students' reading comprehension improvement. Based on observation cheklist and field notes, during the implemention of cognitive strategy the students were active to read the text. The interview result also shows that the students were active during the implementation of cognitive strategy. Below is the sample of scripts from the collaborator's questions and students answer during interview section:

Collaborator : "Do you like study reading through cognitive strategy?"

Students 1 : "Yes, Mrs, Because it is the first time for me".

Students 2 : "Because it's new for me, I'm more motivated Mrs".

Students 4 : "Yes I do, I can't wait Highlighting part Mrs, because I can give color to my text".

Collaborator : "What do you think about the teacher, does she motivate you?"

Students 5 : The teacher motivates me during the class, she helps me when I get problem".

Students 7 : "Yes Mrs, the teacher helps me. I can ask her during the class. She's passionate about what she taught".

Student 9 : "Yes mrs, she encourage and motivate us to study well"

Student 10 : She is so energetic and enthusiastic. It is a lot harder for us to fall asleep.

In brief, the students were motivated to ask and learn together. Moreover, in discussing class, the student were motivated to answer. It could be seen from the activeness to answer the questions. Interestingly, the teacher's motivation played the important role in this reading activity. The observation checklist and field notes show the teacher motivated their students alot. They motivated their students to read and answer well.

\section{Teacher's role}

The interview result supported the third factor because the collaborator also offered a question which related to the roles of teacher during the teacher and learning process through cognitive strategy. Below is the sample of scripts from the collaborator's questions and students answer during interview section:

Collaborator : "What do you think about teacher's role and the step of cognitive strategy?".

Student 2 : "I like when she always guides us do the strategy".

Student 4 : "I'm confused since its new Mrs. But then she explains it clearly and she also guides us in each part of cognitive strategy".

Students 6 : “I understand teacher's explanation Mrs. She also monitoring our work". 
Students 7 : "Clear Mrs, teacher helps me to comprehend each steps of cognitive strategy".

Students 9 : "She guides and manages the class well. She always explains the procedures of cognitive strategy in order."

It means that the roles of the teacher in the class were still needed by the students because the teacher did not only have a single role in the class, but she also had to monitor, observe, guide, and help the students during the teaching and learning process through cognitive strategy because some of procedures need the students to participate actively.

Overall, using cognitive strategy in solving the teaching and learning problem in reading has brought significant improvements on students reading comprehension during two cycles. It means the use of cognitive strategy could better improve students' reading comprehension. The improvement was concluded through the data gathered from the result of the reading comprehension tests, observation and interview. Finally, this finding is line with theories that cognitive strategy is an effective strategy of teaching. Students may be taught to use cognitive strategy such as generating question about their reading. From Rosenshine and Meister's statement, it could be inferred that while generating questions, the students need to search the text and combine the information, which in turn helps them comprehend what they read. The findings of this research also revealed that after taught reading comprehension of descriptive texts through cognitive strategy, the students can get the gist of the text. It is supported by Syatriana (2012) who state that the cognitive strategy such as prediction, decoding, paraphrasing and inference that have been taught of the text, to get the meaning of difficult words, to draw an inference, get factual information and many details of information. She also found that cognitive strategy could improve students' reading comprehension. In her classroom, she found that each activity of cognitive strategy influenced the students reading development.

The improvement of reading comprehension by using cognitive strategy was also supported by Khezrlou (2012). It has been found that the training provided by the teacher contributes to the FLL process, and learners' awareness of the accurate use of the cognitive strategy increases. The results suggest that teachers' explicit instruction and assistance of learners' strategy use during a particular activity are linked with the learners' effective use of strategies. 


\section{DISCUSSION}

This research was done to find out to what extent cognitive strategy can improve students' reading comprehension and what factors influence the changes of students' reading comprehension at grade VII-2 of SMP Negeri 1 Tembilahan. Based on the result of the research, it can be concluded that:

1. The use of Cognitive strategy improves the students' reading comprehension of descriptive texts at grade VII-2 SMPN 1 Indra Praja. There were significant improvement to the students' score of reading comprehension test from pre-test, cycle I and II. The average score of students' score in the pre-test was only 63.15, in cycle I the average of the students' score increased become 70.72, and in cycle II increased become 78.10. It means that the students' average score in cycle II could reach the minimum criteria of achievement of English subject at SMP Negeri 1ndra Praja Tembilahan that is 75.

2. The factors that influenced the changes of the students' reading comprehension through cognitive strategy are:

\section{a. The unknown teaching materials.}

Researcher found that the unknown descriptive texts influenced the students' reading comprehension. An interesting material can increase the students' curiosity, they were motivated to comprehend the texts.

\section{b. Students' motivation}

Based on the data from the research, the students had high motivation and enjoy the reading activities by using the cognitive strategy. It was very helpful for the students in comprehending descriptive texts. In addition, the result of interviews showed that the students were interested in using Cognitive strategy because it was a new strategy for them.

\section{c. Teacher's role}

In Cognitive strategy, the teacher gave guidance and explanation to the students. The existence of the teacher really needed because he had a great influence during the teaching and learning process. The guiding activities that the students had to do during teaching and learning process by using Cognitive strategy was the one of the factors that influenced the improvement of students. 
Finally, for the sake of facilitating English teacher in teaching reading comprehension of descriptive texts, particularly by using cognitive strategy, the researcher suggests as in the following:

1. Since cognitive strategy was a useful teaching and learning strategy, it was suggested that other teachers could try this strategy in teaching other language skills not only reading.

2. It was suggested for other teachers who are interested in using cognitive strategy to use other types of cognitive strategy.

\section{REFERENCES}

Burnes and Page,G. (2007). Insight strategies for teaching reading. New York: Harcourt Brace Jovanich Group. Pty Limited.

Cavanagh, Jane. (2008). Text types. English K-6 Syllabuss. Retrieved from: http:// goldfieldsliteracy. wikispaces.com /file/view/Yvonne++Text+Types+_A_+-+PDF. pdf.

Gerot, L. and Wignell,P. (2008). Making sense of functional grammar. Australia: Gerd Stabler.

Hopkins, D. (2008). A teacher's guide to classroom research. Philadelphia: Open University Press.

Kemmis, Stephen and Mc Taggart Robin.(2008).The action research planner. Victoria: Deakin University.

Khezrlou,S. (2012). Cognitive strategy training: Improving reading comprehension in the language classroom. The Journal of Teaching Language Skills. Retrieved from: http://www.teaching.language.skill.journal/JTL53721319920200.pdf.

Sahan, Ahmet. (2012). Cognitive reading comprehension strategies employed by ELT Students. Retrieved from: http://sbe.erciyes.edu.tr/dergi/sayi_33/1.pdf.

Syatriana, Eny. (2012). Developing the students' reading comprehension through cognitive reading strategies of the first year students of SMAN 16 Makassar. Retrieved from: http://www.niu.edu/international/_images/Eny\%20Syatriana.pdf.

Oxford, Rebecca. (2010). Language learning strategies. What every teacher should know. Boston: Heinle\&Heinle. 